\title{
THE ANALYSIS OF PRIMARY SCHOOL TEACHERS' ABILITY IN THE APPLICATION OF ICT-BASED LEARNING MEDIA IN TAROGONG KIDUL DISTRICT
}

\author{
Irfan Hilman, Suci Zakiah Dewi \\ Universitas Garut, Jl. Raya Samarang No.52A \\ Correspondence Email: irfanhilman@uniga.ac.id
}

\begin{abstract}
The purpose of this research is to analyze the ability of elementary school teachers in the application of learning media based on Information and Communication Technology (ICT). The main objectives are the teacher's understanding of ICT-based learning media, the ability of teachers in designing ICT-based learning media, the ability of teachers in the use of ICT-based learning media, factors that can support and inhibit the application of ICT-based learning media, and how teachers overcome obstacles in the application of ict-based learning media. The research method used by the author is mixed methods research method or mixed research method that is, by combining between qualitative and quantitative research types. The subject of this study was a public elementary school teacher in tarogong kidul area. The sample of this study was as many as 30 teachers. Instruments used in the form of questionnaires, observations and interviews. Based on the results of the instrument test obtained teacher's understanding of learning media by $85.6 \%$, the ability of teachers in designing ICT-based learning media by $85.6 \%$, then the ability of teachers in the use of ICT-based learning media by $85.4 \%$. The supporting factors in terms of teacher ability are the implementation of training in the use of ICT devices and designing ICT-based learning media. From the results obtained, it can be concluded that the ability of elementary school teachers in the application of ICT-based learning media in the Tarogong Kidul area is very good.
\end{abstract}

Keywords

learning media, ict, ict, elementary school.

\section{A. INTRODUCTION}

Learning media is important component in supporting the learning process $^{1}$. This is because the learning media can be the main facility for teachers to deliver materials to students so that students can easily understand. Media as the main tool in the learning process that can make it easier for teachers and students to interact in full. Learning media is all forms of arousal and tools provided by teachers to encourage students to learn

\footnotetext{
${ }^{1}$ Andika, Akbar O. (2015). Minat Belajar Siswa terhadap Media Komik Berbasis Pendekatan Saintifik pada Materi Sistem Pencernaan Kelas XI SMA. BioEdu, 4(1).
}

quickly, precisely, easily, correctly, and without verbalism ${ }^{2}$.

Learning media certainly brings the role of a teacher to be more innovative and productive in presenting materials delivered to students in the classroom. Teachers must be good at choosing learning media that can be a motivation for students and communicative in learning in the classroom.

Technology and information develop so rapidly in various aspects of life is no exception in the field of education, is an effort to bridge the present and the

\footnotetext{
2 Yuni, N. (2019). Hubungan Minat Baca dan Penggunaan Media Pembelajaran dengan Hasil Belajar Pendidikan Agama Islam Siswa Smp Negeri 2 Way Jepara Lampung Timur (Doctoral dissertation, IAIN Metro).
} 
future by introducing innovations that tend to pursue efficiency and effectiveness. Innovation in the learning process in the classroom is very necessary considering that in this modern era, the use of ICT is so much needed by teachers and students 3 . Therefore, the use of ICT is mandatory for teachers to be applied in the learning process so that teachers must understand and master the use of ICTbased learning media in depth. One of the requirements of teachers is said to be professional teachers who understand about technology so that teachers are able to design to apply ICT-based learning media in the teaching and learning process ${ }^{4}$. The use of ICT as a learning media certainly has a great contribution and innovation in the world of education. With ICT, it is very easy for teachers to improve their teaching skills. The creativity and skills of teachers can be seen from the use of ICT-based learning media5. Welldesigned learning media will greatly help learners in digesting and understanding the subject matter ${ }^{6}$. It is expected that the use of this media can stimulate the thoughts, feelings, interests and attention of learners in such a way that the learning process can be well-done 7 .

\footnotetext{
${ }^{3}$ Fathurrohman, M. (2017). Belajar dan Pembelajaran Modern: Konsep Dasar, Inovasi dan Teori Pembelajaran. Garudhawaca.

4 Al-Tabany, T. I. B. (2017). Mendesain Model Pembelajaran Inovatif, Progresif, Dan Konteksual. Prenada Media.

${ }^{5}$ Rohman, M. G., \& Susilo, P. H. (2019). Peran Guru Dalam Penggunaan Media Pembelajaran Berbasis Teknologi Informasi Dan Komunikasi (TIK) Studi Kasus Di TK Muslimat NU Maslakul Huda. Jurnal Reforma, 8(1), 173177.

6 Muhson, A. (2010). Pengembangan media pembelajaran berbasis teknologi informasi. Jurnal Pendidikan Akuntansi Indonesia, 8(2)

${ }^{7}$ Dewi, S. Z., \& Hilman, I. (2018). Penggunaan TIK sebagai Sumber dan Media Pembelajaran
}

Some previous research related to ICT has been done a lot, the first is research on the influence of ICT-based learning in improving science learning in elementary school ${ }^{8}$. The next research is about ICT-based science learning towards improving ict literacy of elementary school students 9 . Furthermore, the influence of ICTbased social studies learning using Lectora Inspire in improving learning outcomes from textbooks at SD Negeri Gedongtengen Yogyakarta ${ }^{10}$.

Looking at some previous research the subject of research on ICT is more focused on elementary school students. In this research, researchers took a position in this study to analyze the ability of elementary school teachers to ict-based learning, namely to examine the extent to which elementary teachers know and are able to design and use ICT-based learning as well as what obstacles and how teachers overcome obstacles in the application of ICT-based learning media.

In the era of industrial revolution 4.0 ict utilization is an inevitability. The information and media obtained by elementary school students today has been so fast and massive. The

Inovatif di Sekolah Dasar. Indonesian Journal of Primary Education, 2(2), 48-53.

${ }^{8}$ Nurdyansyah \& Luly Riananda. (2016). 1137-2614-1SM.pdf. Proceedings of International Research Clinic \& Scientific Publications of Educational Technology, 929-940. Retrieved from https://journal.unesa.ac.id/index.php/jtp/article/ view/1137

9 Mustika, E. (2013). PEMBELAJARAN SAINSBERBASIS ICTUNTUK MENINGKATKAN ICT LITERACYSISWA SEKOLAH DASAR. PEDAGOGIK (JURNAL PENDIDIKAN SEKOLAH DASAR), 1(2), 3040.

${ }^{10}$ Maria Zulfiati, H. (2015). Pengaruh Pembelajaran Ips Berbasis Ict (Information and Communications Technology) Dengan Aplikasi Lectora Inspire Dalam Meningkatkan Hasil Belajar Siswa. Jipsindo, $\quad 1(1), \quad 39-58$. https://doi.org/10.21831/jipsindo.v1i1.2878 
momentum must be taken and minimized. Therefore, some of the things that are the urgency of this research include:

a. Elementary school age children are a rapid age range of learners, therefore the introduction of ICT is very appropriate at that time.

b. There are still many elementary school teachers in Garut area who are still not "awarness" to ICTbased learning

This research is in line with the Strategic Plan 2015-2019 Directorate General of Strengthening Research and Development on Information and Communication Technology, the development of information and communication technology is intended to reduce information gaps.

The purpose of this research is to analyze the ability of elementary school teachers in the application of ICTbased learning media. The main objectives are to better know the teacher's understanding of ICT-based learning media, the ability of teachers in designing ICT-based learning media, the ability of teachers in the use of ICTbased learning media, factors that can support and inhibit the application of ICT-based learning media, and how teachers overcome obstacles in the application of ict-based learning media. ICT-based learning media that became the benchmark in this research is learning media using power point application, where this application is a simple application but it is quite complete, ranging from the use of language, photos, videos, writing, color to anmasi. From some research that the use of powerpoint applications can improve the learning outcomes and motivation of children in the learning process 11.

The result of this research is to be able to know the extent of teachers' ability in the application of ICT-based learning media and if there are still shortcomings can be followed up with the holding of trainings for teachers in the application of ICT-based learning media.

The research method used is mixed methods research method or mixed research method that is, by combining the type of qualitative research with quantitative. Mixed research method is a research approach by compensing between quality research and quantitative research 12. Data collection instruments in this research use qualitative and quantitative techniques. Qualitative techniques using interview and observation guidelines. Quantitative techniques by spreading questionnaires to teachers as field trial subjects,13. Data analysis in this research using quantitative-

\footnotetext{
11 Nursyaida, N., \& Hardiyanti, A. (2020). EFEKTIVITAS PENGGUNAAN MEDIA POWER POINT TERHADAP HASIL BELAJAR IPS KELAS V SD 128 TURUNGAN BERU KECAMATAN HERLANG KABUPATEN BULUKUMBA. JRPD (Jurnal Riset Pendidikan Dasar), 3(1), 71-76.
}

12 Creswell, J. W. (2014). RESEARCH DESIGN, Qualitative, Quantitative, and Mixed Methods Approaches atau RESEARCH DESIGN: Pendekatan Metode Kualitatif, Kuantitatif, dan Campuran, Terjemahan Achmad Fawaid \& Rianayati Kusmini P. 2016. Yogyakarta: Pustaka Pelajar.

13 Ashari, L. H., Lestari, W., \& Hidayah, T. (2016). Instrumen Penilaian Unjuk Kerja Siswa Smp Kelas Viii Dengan Model Peer Asssessment Berbasis Android Pada Pembelajaran Penjasorkes Dalam Permainan Bola Voli. Journal of Research and Educational Research Evaluation, 5(1), 08-20. 
qualitative data analysis gradually, namely by way of analysis is done by means of quantitative data and then followed by cauldronative data. The subject of this study was a class teacher at SD Negeri in tarogong kidul. The sample of this study was as many as 30 classroom teachers.

\section{B. RESULTS AND DISCUSSION 1. RESULTS}

This research was conducted through 30 public elementary school teachers in Tarogong kidul. Data

Table 1

Analysis of teacher's understanding of ICT-based learning media

\begin{tabular}{ccccc}
\hline Indicators & \multicolumn{3}{c}{ Item } & Low \\
\cline { 2 - 5 } & Very Good & Good & $\begin{array}{c}\text { Good } \\
\text { Enough }\end{array}$ & \\
\hline $\begin{array}{c}\text { Understanding } \\
\text { ICT-based } \\
\text { learning } \\
\text { media }\end{array}$ & $56 \%$ & $34 \%$ & $8 \%$ & $\mathbf{2 \%}$ \\
\end{tabular}

Based on table 1 it was obtained that teachers' understanding of ICT-based learning media is $56 \%$ excellent, $34 \%$ good, $8 \%$ sufficient and $2 \%$ low. So it can be concluded that teachers' understanding of ICT-based learning media is very good. collection in this study uses questionnaires as quantitative data. The questionnaire consists of three indicators that will be researched, namely the teacher's understanding of ICT-based learning media, the use of ICT-based learning media, and the creation of ICT-based learning media.

Based on the results of data analysis on the questionnaire answer sheet at the teacher's level of understanding about ICT-based learning media are as follows:
Based on the results of data analysis on the questionnaire answer sheet at the level of use of ICT-based learning media in the learning process are as follows:

Table 2

Questionnaire Analysis of ICT-Based Learning Media Use

\begin{tabular}{ccccc}
\hline Indicator & \multicolumn{4}{c}{ Item } \\
\cline { 2 - 5 } & Very Good & Good & $\begin{array}{c}\text { Good } \\
\text { Enough }\end{array}$ & Low \\
\hline $\begin{array}{c}\text { Use of ICT- } \\
\text { based } \\
\begin{array}{c}\text { Learning } \\
\text { Media }\end{array}\end{array}$ & $53 \%$ & $37 \%$ & $\mathbf{8 \%}$ & $\mathbf{2 \%}$ \\
& & & &
\end{tabular}

Based on table 2 obtained that the use of ICT-based learning media there are $53 \%$ excellent, $37 \%$ good, $8 \%$ sufficient and $2 \%$ low. So it can be concluded that the use of teachers in implementing ICT-based learning media is very good. 
Based on the results of data analysis on

level

of

the questionnaire answer sheet at the

teacher ability in terms of making ICT-based learning media is as follows.

Table 3

Questionnaire Analysis of Teacher's Level of Ability in Creating

ICT-Based Learning Media

\begin{tabular}{ccccc}
\hline Indicator & \multicolumn{4}{c}{ Item } \\
\cline { 2 - 5 } & Very Good & Good & $\begin{array}{c}\text { Good } \\
\text { Enough }\end{array}$ & Low \\
\hline $\begin{array}{c}\text { ict-based } \\
\text { learning } \\
\text { media } \\
\text { creation }\end{array}$ & $54 \%$ & $36 \%$ & $\mathbf{8 \%}$ & $\mathbf{2} \%$ \\
& & & & \\
\end{tabular}

Based on table 3 obtained that the ability of teachers in the manufacture of ICT-based learning media there are $54 \%$ excellent, $36 \%$ good, $8 \%$ sufficient and $2 \%$ low. So it can be concluded that the ability of teachers in making ICTbased learning media is very good.

To support the results of quantitative data, the researchers conducted interviews and observations as qualitative data directly on the research subject. From obeservation results obtained that teachers in the manufacture of ICT-based learning media can be seen from the selection of types and sizes of fronts can be seen clearly by students. Similarly, the selection of color composition makes students interested in the learning media that teachers display.

Another aspect that teachers already have is graphics in the making of media is skilled as well as the selection of photos used can attract students, so that students will pay more attention to the learning media created by the teacher. Another thing that is very important in the making of media is that the narrative conveyed is easy to understand proven from the arrangement of music and sound effects are already good. Students' learning interest by using power-point application media is seen from how teachers place photos related to the material interestingly and how teachers pair music with animation effects 14 . In the making of this media is equipped with explanation of terms so that students do not have difficulty understanding the material and the use of language in the making of learning media is very understood by students.

From the results of the interview obtained data that almost all teachers have participated in ict-based learning media making training in this case office power point training that was rushed by their respective schools. The difficulty faced by teachers in the storage of ICT-based learning media is the limited means of LCD projectors so that their use must take turns, while the solution to overcome it is to divide the schedule of use.

Thus, from the results of interviews and observations it can be concluded that teachers can make ict learning media very well and able to overcome the difficulties faced in the process of

\footnotetext{
${ }^{14}$ Elpira, N., \& Ghufron, A. (2015). Pengaruh penggunaan media powerpoint terhadap Minat dan hasil belajar ipa siswa kelas IV SD. Jurnal Inovasi Teknologi Pendidikan, 2(1), 94-104.
} 
using ICT-based learning media so that the learning process looks more enjoyable so that students are more enthusiastic in learning. in line with what Kusumah said in 15. Interesting learning should facilitate students to successfully achieve optimal learning goals in an easy, fast and fun way. Students in the classroom also become more motivated and enthusiastic in learning in the classroom by using ICTbased learning media. Students become passionate in learning, finding knowledge and related information delivered by teachers and thinking more broadly.

\section{DISCUSSION}

This research uses Mix Method research method which is a mixed research method where this method combines quantitative method and qualitative method. stated that mixed methods is a research method that combines or combines quantitative methods with qualitative methods to be used jointly in a research activity, so that more comprehensive, valid, reliable and objective data are obtained16. For quantitative data using questionnaires, questionnaires are made in the form of multiple choices with the Likert scale model ${ }^{17}$. After the questionnaire was first tested validity and reliability ${ }^{18}$. Based on the results of data processing through SPSS the

\footnotetext{
${ }^{15}$ Lestari, I. D. (2018). Peranan guru dalam penggunaan media pembelajaran berbasis information and communication technology (ICT) di SDN RRI cisalak. SAP Artikel Pendidikan), 3(2).
}

\footnotetext{
${ }^{16}$ Sugiyono, P. (2015). Metode penelitian kombinasi (mixed methods). Bandung: Alfabeta.

17 Budiaji, W. (2013). Skala pengukuran dan jumlah respon skala likert. Jurnal ilmu pertanian dan perikanan, 2(2), 127-133.

${ }^{18}$ Yusup, F. (2018). Uji validitas dan reliabilitas instrumen penelitian kuantitatif. Tarbiyah: Jurnal Ilmiah Kependidikan, 7(1).
}

questionnaire used has high reliability and validity of items above 0.03 it indicates that the poll is declared valid. Qualitative techniques using interview and observation guidelines. In order for the interview to be effective, there are several stages that must be passed, namely; 1). introduce yourself; 2). explain the purpose of arrival; 3). describe the interview material; and 4). asking questions. For observation techniques, this research uses unstructured observation techniques, namely observations made without using observation guidelines, so that researchers develop their observations based on developments that occur in the field 19 .Tahapan pelaksanaan pencarian data diawali dengan membagikan angket pertanyaan kepada guru untuk mengetahui sejauh mana guru memahami media pembelajaran berbasis ICT, selain itu untuk mengetahui intensitas guru dalam penggunaan media pembelajaran berbasis ICT dan bagaimana kemampuan guru dalam membuat media pembelajaran berbasis ICT.

Mastery of ICT learning media for teachers is now a necessity and demand in this digital era so that it requires teachers to master the use of ICT. From the results obtained both kuantitaif data and quality data can be concluded that the ability of teachers in the use of ICT-based learning media in elementary school Tarogong Kidul sanagat good. This research is almost in accordance with the research conducted by. with the title Teacher competence in utilizing the media of ICT-based learners at SD negeri 16 Banda Aceh where the research can be concluded that the competencies

19 Rahardjo, M. (2011). Metode pengumpulan data penelitian kualitatif. 
owned by teachers in utilizing ICTbased learning media are quite good. However, there is still a lot of guidance in finding media and learning resources from the internet. ${ }^{20}$

To become a professional teacher, teachers must have several criteria, one of which is that teachers can apply ICT based on learning, ${ }^{21}$. In line with what ${ }^{22}$ Teacher Competency Standards that must be mastered in ICT mastery are:

1. Operates its personal and peripheral computers

2. Assemble, install, set-up, maintain and track and troubleshoot problems on personal computers

3. Doing computer programming with one of the object-oriented programming languages

4. Processing words ( word processing) with a personal computer

5. Process worksheets and graphs with a personal computer

6. Manage the database (data base) with a personal computer or server computer

7. Create interactive presentations that meet the rules of visual and interpersonal communication.

\section{CONCLUSION}

Based on the results of the questionnaire that has been filled by teachers processed the data as follows:

20 Yusrizal, Y., Safiah, I., \& Nurhaidah, N. (2017). Kompetensi Guru Dalam Memanfaatkan Media Pembelajaran Berbasis Teknologi Informasi Dan Komunikasi (TIK) Di SD Negeri 16 Banda Aceh. Jurnal Ilmiah Mahasiswa Pendidikan Guru Sekolah Dasar, 2(2).

${ }^{21}$ Mugara, R. (2011). Meningkatkan kompetensi guru melalui penguasaan teknologi informasi dan komunikasi (TIK). Prodi Pengembangan Kurikulum. Universitas Pendidikan Indonesia. Sunan Kalijaga: Yogyakarta.

22 Wijayanti, I. D. (2011). Peningkatan Pendidikan Berbasis ICT. UIN Sunan Kalijaga: Yogyakarta.
1. Teachers' understanding of ICTbased learning media is $56 \%$ excellent, $34 \%$ good, $8 \%$ sufficient and $2 \%$ low. So it can be concluded that teachers' understanding of ICT-based learning media is very good.

2. The use of ICT-based learning media is $53 \%$ excellent, $37 \%$ good, $8 \%$ sufficient and $2 \%$ low. So it can be concluded that the use of teachers in implementing ICT-based learning media is very good.

3. The ability of teachers in the manufacture of ICT-based learning media is $54 \%$ excellent, $36 \%$ good, $8 \%$ sufficient and $2 \%$ low. So it can be concluded that the ability of teachers in making ICT-based learning media is very good.

In addition, based on the results of interviews and obervasi processed that teachers in the manufacture of ICT-based learning media has been very good, can be seen from the selection of types and sizes of fronts can be seen clearly by students. Similarly, the selection of color composition makes students interested in the learning media that teachers display. Another aspect that teachers already have is graphics in the making of media is skilled as well as the selection of photos used can attract students, so that students will pay more attention to the learning media created by the teacher. The most important thing in media making is that the narrative conveyed is easy to understand proven from the arrangement of music and sound effects are already good. In the making of this media is equipped with explanation of terms so that students do not have 
difficulty understanding the material and the use of language in the making of learning media is very understood by students.

Based on the findings obtained from the results of the study, it can be concluded that the ability of elementary school teachers in the Tarogong Kidul area of Garut district in the use of ICT-based learning media is very good.

\section{ACKNOWLEDGEMENTS}

Researchers thanked the relevant parties including the Ministry of Education and Education who have provided research funds and schools that have given permission to carry out research. Not to forget also the whole team that has helped this research.

\section{BIBLIOGRAPHY}

Andika, Akbar O. (2015). Minat Belajar Siswa terhadap Media Komik Berbasis Pendekatan Saintifik pada Materi Sistem Pencernaan Kelas XI SMA. BioEdu, 4(1).

Yuni, N. (2019). Hubungan Minat Baca dan Penggunaan Media Pembelajaran dengan Hasil Belajar Pendidikan Agama Islam Siswa Smp Negeri 2 Way Jepara Lampung Timur (Doctoral dissertation, IAIN Metro).

Fathurrohman, M. (2017). Belajar dan Pembelajaran Modern: Konsep Dasar, Inovasi dan Teori Pembelajaran. Garudhawaca.

Al-Tabany, T. I. B. (2017). Mendesain Model Pembelajaran Inovatif, Progresif, Dan Konteksual. Prenada Media.

Rohman, M. G., \& Susilo, P. H. (2019). Peran Guru Dalam Penggunaan Media Pembelajaran Berbasis Teknologi Informasi Dan Komunikasi (TIK) Studi Kasus
Di TK Muslimat NU Maslakul Huda. Jurnal Reforma, 8(1), 173177.

Muhson, A. (2010). Pengembangan media pembelajaran berbasis teknologi informasi. Jurnal Pendidikan Akuntansi Indonesia, 8(2)

Dewi, S. Z., \& Hilman, I. (2018). Penggunaan TIK sebagai Sumber dan Media Pembelajaran Inovatif di Sekolah Dasar. Indonesian Journal of Primary Education, 2(2), 48-53.

Nurdyansyah \& Luly Riananda. (2016). 1137-2614-1-SM.pdf. Proceedings of International Research Clinic $\mathcal{E}$ Scientific Publications of Educational Technology, 929940. Retrieved from https://journal.unesa.ac.id/index .php/jtp/article/view/1137

Mustika, E. (2013). PEMBELAJARAN SAINSBERBASIS ICTUNTUK MENINGKATKAN ICT LITERACYSISWA SEKOLAH DASAR. PEDAGOGIK (JURNAL PENDIDIKAN SEKOLAH DASAR), 1(2), 30-40.

Maria Zulfiati, H. (2015). Pengaruh Pembelajaran Ips Berbasis Ict (Information and Communications Technology) Dengan Aplikasi Lectora Inspire Dalam Meningkatkan Hasil Belajar Siswa. Jipsindo, 1(1), 3958.

https://doi.org/10.21831/jipsindo. vii1. 2878

Nursyaida, N., \& Hardiyanti, A. (2020). EFEKTIVITAS PENGGUNAAN MEDIA POWER POINT TERHADAP HASIL BELAJAR $\begin{array}{lllll}\text { IPS } & \text { KELAS } & \mathrm{V} & \text { SD } & 128\end{array}$ TURUNGAN BERU KECAMATAN HERLANG KABUPATEN 
BULUKUMBA. JRPD (Jurnal Riset Pendidikan Dasar), 3(1), 7176.

Creswell, J. W. (2014). RESEARCH DESIGN, Qualitative, Quantitative, and Mixed Methods Approaches atau RESEARCH DESIGN: Pendekatan Metode Kualitatif, Kuantitatif, dan Campuran, Terjemahan Achmad Fawaid \& Rianayati Kusmini P. 2016. Yogyakarta: Pustaka Pelajar.

Ashari, L. H., Lestari, W., \& Hidayah, T. (2016). Instrumen Penilaian Unjuk Kerja Siswa Smp Kelas Viii Dengan Model Peer Asssessment Berbasis Android Pada Pembelajaran Penjasorkes Dalam Permainan Bola Voli. Journal of Research and Educational Research Evaluation, 5(1), o8-20.

Elpira, N., \& Ghufron, A. (2015). Pengaruh penggunaan media powerpoint terhadap Minat dan hasil belajar ipa siswa kelas IV SD. Jurnal Inovasi Teknologi Pendidikan, 2(1), 94-104.

Lestari, I. D. (2018). Peranan guru dalam penggunaan media pembelajaran berbasis information and communication technology (ICT) di SDN RRI cisalak. SAP (Susunan Artikel Pendidikan), 3(2).

Sugiyono, P. (2015). Metode penelitian kombinasi methods). Bandung: Alfabeta.

Budiaji, W. (2013). Skala pengukuran dan jumlah respon skala likert. Jurnal ilmu pertanian dan perikanan, 2(2), 127-133.

Yusup, F. (2018). Uji validitas dan reliabilitas instrumen penelitian kuantitatif. Tarbiyah: Jurnal Ilmiah Kependidikan, 7(1).

Rahardjo, M. (2011). Metode pengumpulan data penelitian kualitatif. Yusrizal, Y., Safiah, I., \& Nurhaidah, N. (2017). Kompetensi Guru Dalam Memanfaatkan Media Pembelajaran Berbasis Teknologi Informasi Dan Komunikasi (TIK) Di SD Negeri 16 Banda Aceh. Jurnal Ilmiah Mahasiswa Pendidikan Guru Sekolah Dasar, 2(2).

Mugara, R. (2011). Meningkatkan kompetensi guru melalui penguasaan teknologi informasi dan komunikasi (TIK). Prodi Pengembangan Kurikulum. Universitas Pendidikan Indonesia. Sunan Kalijaga: Yogyakarta.

Wijayanti, I. D. (2011). Peningkatan Pendidikan Berbasis ICT. UIN Sunan Kalijaga: Yogyakarta. 